\title{
Biopsy of Mouth
}

National Cancer Institute

\section{Source}

National Cancer Institute. Biopsy of Mouth. NCI Thesaurus. Code C51650.

Removal of tissue from the oral cavity for microscopic examination. 